\title{
Effects of climate, soil, forest structure and land use on the functional composition of the understorey in Italian forests
}

\author{
Stefano Chelli ${ }^{1}$ (D) | Enrico Simonetti ${ }^{1}$ | Camilla Wellstein ${ }^{2}$ | Giandiego Campetella ${ }^{1}$ | \\ Stefano Carnicelli ${ }^{3}$ | Anna Andreetta ${ }^{3}$ | Daniele Giorgini ${ }^{1}$ | Nicola Puletti ${ }^{4}$ | \\ Sandor Bartha ${ }^{5,6}$ | Roberto Canullo ${ }^{1}$
}

${ }^{1}$ School of Biosciences and Veterinary Medicine, Plant Diversity and Ecosystems Management Unit, University of Camerino, Camerino, MC, Italy

${ }^{2}$ Faculty of Science and Technology, Free University of Bozen-Bolzano, Bozen, Italy

${ }^{3}$ Department of Earth Sciences, University of Florence, Firenze, Italy

${ }^{4}$ CREA Research Centre for Forestry and Wood, Trento, Italy

${ }^{5}$ Institute of Ecology and Botany, MTA Centre for Ecological Research, Vácrátót, Hungary

${ }^{6} \mathrm{GINOP}$ Sustainable Ecosystems Group, MTA Centre for Ecological Research, Tihany, Hungary

\section{Correspondence}

Stefano Chelli, School of Biosciences and Veterinary Medicine, Plant Diversity and Ecosystems Management Unit, University of Camerino, Via Pontoni 5, I-62032 Camerino, MC, Italy.

Email: stefano.chelli@unicam.it

Funding information

SB was supported by the

GINOP-2.3.2-15-2016-00019 project.

Co-ordinating Editor: Jodi Price

\begin{abstract}
Question: In functional biogeography studies, generalizable patterns in the relationship between plant traits and the environment have yet to emerge. Local drivers (i.e., soil, land use, vegetation structure) can increase our understanding of the trait-environment relationship. What is the role of climate and local drivers in shaping abundance-weighted trait patterns of forest understories at biogeographic scales? Location: Italian forests.

Methods: We selected 201 sites that are statistically representative for the heterogeneity of Italian forests across three biogeographic regions (alpine, continental, and mediterranean). Understorey vegetation was recorded for each site on an area of $400 \mathrm{~m}^{2}$, together with 25 environmental variables related to climate, soil, land use and forest structure. Specific leaf area (SLA), plant height $(H)$ and seed mass (SM) were obtained from databases. Community-weighted mean (CWM) values were calculated. Variance partitioning was used to identify the relative role of groups of environmental variables on the CWM of traits. Generalized Additive Models were used to assess the relationship between traits and single variables.

Results: Climate alone and climate-soil interactions explained the largest proportion of the variation of all the traits (13.7\% to $22.8 \%$ ). Temperature-related factors as well as soil $\mathrm{N}$ and $\mathrm{P}$ availability were the climatic and edaphic explanatory variables most correlated to trait variation. Forest structure and land use accounted for a smaller percentage of the variation in traits. Land-use factors alone were important in explaining only SLA variation.

Conclusions: While climate plays a major role in trait-environment relationships in forest understories, our results highlighted the need to integrate at least soil properties as local drivers of trait variation in broad scale functional biogeography studies of these systems.
\end{abstract}

\section{KEYWORDS}

Climate-soil interactions, Community-weighted mean, functional biogeography, plant height, seed mass, specific leaf area, temperature seasonality, trait-environment relationship 


\section{1 | INTRODUCTION}

Numerous studies have assessed the relationships between the environment and key plant functional traits on a broad scale (Moles et al., 2009, 2014; Šímová et al., 2018; Wright et al., 2004, 2005) that reflect fundamental plant strategies [Leaf-Height-Seed traits (LHS); Westoby, 1998]. However, generalizable patterns have yet to emerge (Shipley et al., 2016): trait-environment correlations are often weak, and the strength and sign of these correlations vary across studies (Borgy et al., 2017a; Moles et al., 2014; Šímová et al., 2018). These inconsistent results might be due to a variety of factors, including differences in the spatial scale examined in the studies, different methodological approaches, sparsity of data, and differences in the availability of trait data across species and plots (Borgy et al., 2017a; Borgy et al., 2017b; Shipley et al., 2016). In particular, large-scale studies generally include climatic drivers but tend to ignore local drivers (Borgy et al., 2017a) such as soil nutrient status (Le Bagousse-Pinguet et al., 2017; Tautenhahn et al., 2008; Zemunik, Turner, Lambers, \& Laliberté, 2015) and land use (Hedwall \& Brunet, 2016; Pakeman, Lepš, Kleyer, Lavorel, \& Garnier, 2009). Additionally, many studies did not account for plant community organization (i.e., species abundance; Borgy et al., 2017b), thus giving the same weight to all species present in the defined spatial unit. Therefore, to date, there is a lack of knowledge about the extent to which climate, soil and land use control the variation of key plant functional traits at biogeographical scales, taking into account species abundances (i.e., using community-weighted mean values, CWM; Borgy et al., 2017a; but see also Pakeman et al., 2009; Bruelheide et al., 2018).

Broad-scale approaches dealing with functional trait-environment relationships in forest ecosystems have generally focused on woody species, as they account for most of the forest biomass (Gilliam, 2014). These studies found climate to be the primary macro filter acting on the functional structure of tree communities (Shiono et al., 2015; Swenson \& Weiser, 2010). In detail, variables related to climate harshness (minimum/maximum temperature and precipitation) and seasonality (temperature and precipitation seasonality) showed a pervasive effect on key functional traits related to fundamental plant strategies (i.e., specific leaf area, seed mass, plant height; Swenson \& Weiser, 2010; Shiono et al., 2015). However, local soil properties play a significant role in determining community traits at large scales, both alone and in interaction with climate (Ordonez et al., 2009; Simpson, Richardson, \& Laughlin, 2016). For example, soil fertility (available phosphorus) and soil pH in combination with climate drivers were found to be important determinants of leaf, root and seed traits in dominant tree species of temperate forests (Simpson et al., 2016).The majority of the plant diversity in temperate forests is in the understorey and these species play a vital role in forest ecosystem functioning (Gilliam, 2014). Fewer scholars in forest ecosystems have considered determinants of understorey functional composition. The traits of the understorey, like those of trees, are strongly shaped by macroclimate (see Vanneste et al., 2019, for boreo-nemoral forests of Europe). Also, evidence suggests that the understorey has a functional response (e.g., changes in photosynthetic rates) to local variations in soil nutrient availability (Gilliam, 2006; Hättenschwiler \& Körner, 1996; Hedwall \& Brunet, 2016). However, there is still a dearth of studies assessing the effect of soil and climate-soil interactions on understorey traits on a broad scale. Filling this gap is fundamental for improving our ability to predict the effects of global changes (e.g., climate change, nitrogen deposition) on forest ecosystems (Gilliam, 2014; Lavorel \& Garnier, 2002). Additional factors related to forest structure and land use can have an impact on the functional composition of the understorey (Campetella et al., 2011; Cervellini et al., 2017; Verheyen, Honnay, Motzkin, Hermy, \& Foster, 2003). For example, the tree canopy cover and structure, which in turn are shaped by logging activities, can buffer the climate variability (Hedwall \& Brunet, 2016) and influence patterns of light and soil nutrient availability, affecting understorey traits related to dispersal, resource acquisition and competition (Aubin, Gachet, Messier, \& Bouchard, 2007; Aubin, Messier, \& Bouchard, 2008; Bartels \& Chen, 2013; Canullo, Campetella et al., 2011; Dahlgren, Eriksson, Bolmgren, Strindell, \& Ehrlen, 2006; Tonteri et al., 2016). These relationships have mainly been assessed in local studies characterized by homogeneous climatic and edaphic conditions, leaving uncertainty about the effect of land use and forest structure on understorey traits along broad biogeographical gradients (Borgy et al., 2017a).

The aim of our study was thus to assess the broad-scale relationship between abundance-weighted mean trait values of the understorey vegetation and the environment, including climate, soil, land-use and forest structure variables. The three key functional traits of the LHS scheme (namely, specific leaf area, plant height, seed mass; Westoby, 1998) were used since they are associated with the response of plants to the environment (Lavorel \& Garnier, 2002).

In this study, we considered Italy as a model region because it spans an extensive climatic gradient including three biogeographic regions (alpine, continental, and mediterranean) and has a high diversity of soil types due to the great variety of pedogenetic processes (Costantini et al., 2013). These conditions allow for a broad variety of forest types, from alpine coniferous forests to thermophilous broadleaf deciduous and evergreen forests. Moreover, due to a millennial history of human exploitation (Colombaroli \& Tinner, 2013), Italy provides examples of different land-use patterns and its forests feature different types of vegetation structures, from structurally complex old-growth forests to heavily impacted coppice forests.

We ask if: (a) climate acts as the main factor affecting the abundance-weighted trait pattern of the understorey forest vegetation; and (b) local environmental factors (including soil, forest structure and land use) significantly shape CWM traits of the understorey at the studied biogeographical scale.

In addition, we explored the single trait-environment relationships in order to assess the strength and sign of these correlations in forest understories. 


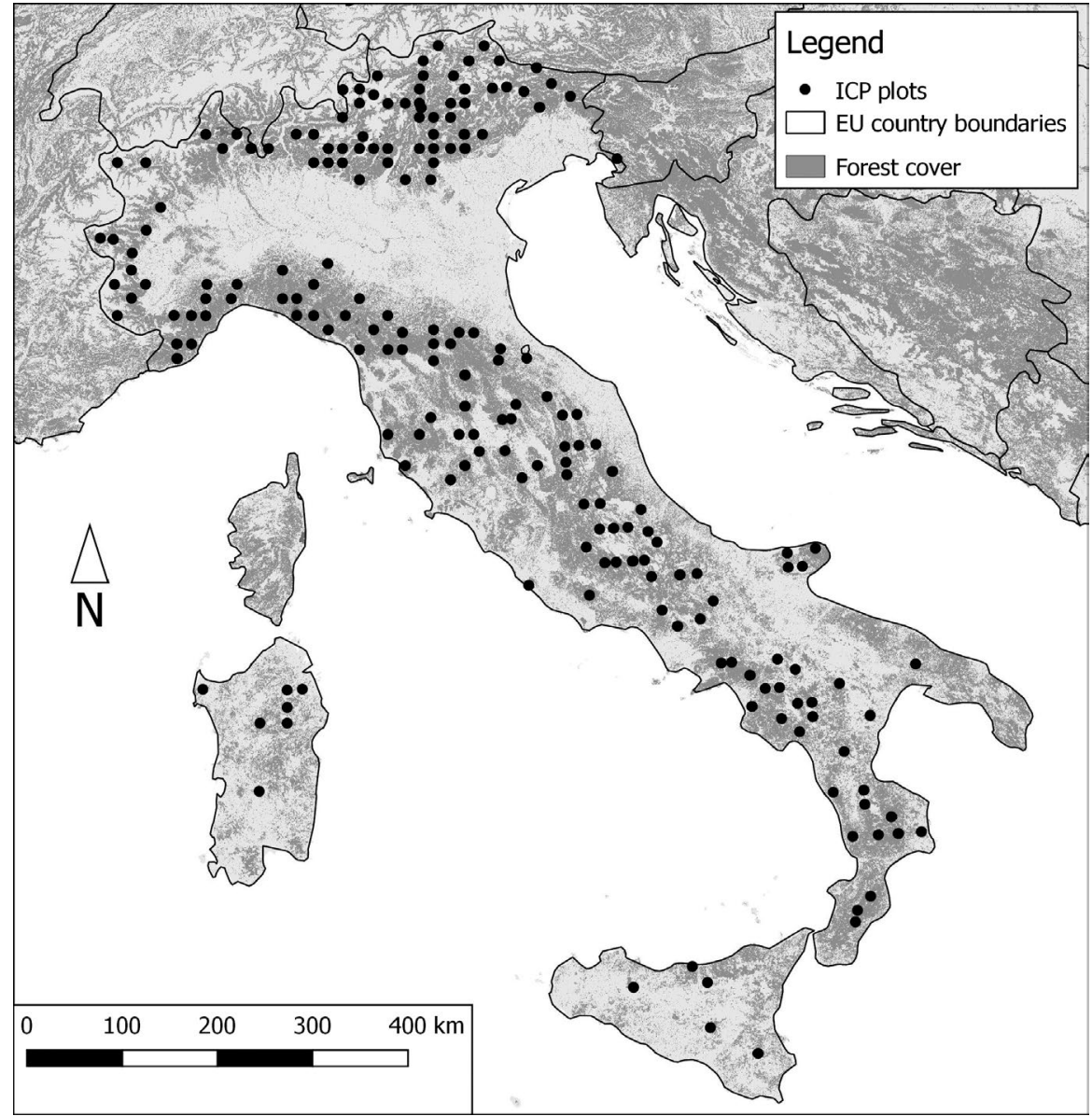

FIGURE 1 Map showing the location of the 201 sampling areas in the context of forest cover in Italy

\section{2 | MATERIALS AND METHODS}

\section{1 | Study area and sampling design}

The study area covers the Italian forests, estimated to be around 9 million hectares, mainly concentrated along the N-S Apennine chains and the $\mathrm{W}$-E disposition of the Alps. Annual mean temperature ranges from $-1.2^{\circ} \mathrm{C}$ to $17.5^{\circ} \mathrm{C}$; annual average rainfall varies between 458 and $1,437 \mathrm{~mm}$. Latitude is comprised between $37.1^{\circ} \mathrm{N}$ and $46.9^{\circ} \mathrm{N}$, including mediterranean, continental and alpine climatic regions. The data used for the present investigation were collected during the BioSoil biodiversity project (WGFB 2011). The sampling design is systematic and probabilistic, allowing a representative picture of Italian forests, useful for avoiding most of the biases contained in traditional vegetation data, for example, subjective decisions on where to locate the sample plots, and for enabling sound generalisations (Chiarucci, 2007). It is based on a grid superimposed upon the whole country with cells of $16 \mathrm{~km} \times 16 \mathrm{~km}$. Each corner of the grid was included as a sample point if a field check found a forest larger than 1 ha there. This system belongs to the transnational Level I network for monitoring the forest health status in Europe (ICP Forests, http://icp-fores ts.net/). For Italy, this resulted in a sample of 201 forest stands
(Figure 1), which were visited in order to record the local plant community composition.

In each forest stand, a total area of $400 \mathrm{~m}^{2}$ was sampled. Data on the presence/absence and coverage (\%) were visually assessed for all vascular plants of the understorey (including shrub layer, $h \leq 5 \mathrm{~m}$ ). The field sampling was done during the spring and summer of 2006, following common protocols, with trained and intercalibrated surveyor teams (see Allegrini, Canullo, \& Campetella, 2009; 2011b).

\section{2 | Explanatory variables}

For each sampling area, we recorded 25 explanatory variables concerning climate, soil, forest structure and land use (Table 1). Variables were either not correlated or very weak to moderate $(r<0.50$; Evans, 1996). Climate variables were obtained from the WorldClim global database (version 1; Hijmans, Cameron, Parra, Jones, \& Jarvis, 2005, time span 1970-2000); among the available parameters, we selected those representing temperature stress (isothermality, temperature seasonality, maximum temperature of the warmest month), water stress [total potential evapotranspiration (PET; Trabucco and Zomer, 2009), precipitation seasonality] and moisture availability (precipitation of the wettest month). 
TAB LE 1 Description of the explanatory variables with units and ranges

\begin{tabular}{|c|c|c|c|c|}
\hline Group & Variable & Unit & Range & Notes \\
\hline \multirow[t]{6}{*}{ Climate } & Total potential evapotranspiration (PET) & $\mathrm{mm}$ & $370-1,065$ & Source: Trabucco and Zomer (2009) \\
\hline & Isothermality & $\%$ & $23-38$ & Source: Hijmans et al. (2005), WorldClim \\
\hline & Temperature seasonality & $\mathrm{CV}(\%)$ & $51-75$ & Source: Hijmans et al. (2005), WorldClim \\
\hline & $\begin{array}{l}\text { Max. temperature of the warmest } \\
\text { month }\end{array}$ & ${ }^{\circ} \mathrm{C}$ & $9.2-31.5$ & Source: Hijmans et al. (2005), WorldClim \\
\hline & Precipitation of the wettest month & $\mathrm{mm}$ & $65-155$ & Source: Hijmans et al. (2005), WorldClim \\
\hline & Precipitation seasonality & CV (\%) & $7-64$ & Source: Hijmans et al. (2005), WorldClim \\
\hline \multirow[t]{6}{*}{ Soil } & Soil pH & $-\log \left(H^{+}\right)$ & $4-8.6$ & Source: Andreetta et al. (2016) \\
\hline & Total N & $\mathrm{g} / \mathrm{kg}$ & $1.2-16.1$ & Source: Andreetta et al. (2013) \\
\hline & $\mathrm{N} / \mathrm{C}$ & na & $0.05-0.19$ & Source: Andreetta et al. (2016) \\
\hline & Subsoil P & $\mathrm{mg} / \mathrm{kg}$ & $55-4,450$ & Source: Andreetta et al. (2016) \\
\hline & Topsoil available $\mathrm{K}$ & $\mathrm{cmol}+/ \mathrm{Kg}$ & $0.01-7$ & Unpublished data \\
\hline & Effective soil volume & $\mathrm{cm}$ & $4.5-170$ & $\begin{array}{l}\text { A good proxy of water holding capacity. } \\
\text { Source: Andreetta et al. (2016) }\end{array}$ \\
\hline \multirow{7}{*}{$\begin{array}{l}\text { Forest } \\
\text { Structure }\end{array}$} & Total vegetation cover & $\%$ & $40-100$ & As biotic driver of vegetation \\
\hline & Litter cover & $\%$ & $2-100$ & As biotic driver of vegetation \\
\hline & Baresoil cover & $\%$ & $0-68$ & As biotic driver of vegetation \\
\hline & Moss cover & $\%$ & $0-72$ & As biotic driver of vegetation \\
\hline & Number of tree layers & Classes & $1-4$ & $\begin{array}{l}1,2,3,>3 \text { tree layers; as indicator of } \\
\text { structural complexity }\end{array}$ \\
\hline & Basal area & $\mathrm{m}^{2} / \mathrm{ha}$ & $2.8-69$ & Related to the total woody biomass \\
\hline & Stem density & n.stems/ha & $100-2,000$ & $\begin{array}{l}\text { Related to the dynamic state and compe- } \\
\text { tition within forest stands }\end{array}$ \\
\hline \multirow[t]{6}{*}{ Land use } & Previous land use & Classes & $1-5$ & $\begin{array}{l}\text { 1, Forested >300 years; } 2 \text {, forested } \\
>100 \text { years; } 3 \text {, forested } 25-100 \text { years; } \\
\text { 4, forested }<25 \text { years; } 5 \text {, unknown }\end{array}$ \\
\hline & Current land use & Classes & $1-4$ & $\begin{array}{l}\text { 1, Unmanaged; } 2 \text {, logged >10 years ago; } \\
\text { 3, logged within } 10 \text { years; } 4 \text {, unknown }\end{array}$ \\
\hline & Stand age & Age classes & 8 classes of 20 years each & Mean age of the dominant storey \\
\hline & Type of management & Classes & $1-4$ & $\begin{array}{l}\text { 1, High forest (i.e., regeneration by } \\
\text { seeds); } 2 \text {, under development to high } \\
\text { forest; } 3 \text {, coppice (i.e., vegetative } \\
\text { regeneration of trees; } 4 \text {, other }\end{array}$ \\
\hline & Total deadwood & $m^{3} / 400 m^{2}$ & $0-15$ & A good proxy of disturbance intensity \\
\hline & Deadwood removal & Binary & $0-1$ & 0, No; 1 , yes \\
\hline
\end{tabular}

The soil variables, measured according to standard procedures (Andreetta, Macci, Giansoldati, Masciandaro, \& Carnicelli, 2013; Andreetta et al., 2011, 2016), are indicative of soil nutrient status [topsoil available potassium (K), and total nitrogen $\mathrm{TN}$ ] and $\mathrm{N}$ availability (N/C; Rowe, Emmett, Smart, \& Frogbrook, 2011), they serve as properties of the parent material (subsoil P), regulate nutrient availability (soil $\mathrm{pH}$ ) and are considered a good proxy of water-holding capacity (effective soil volume).

Variables related to forest structure were measured in the field, including the number of tree layers as an indicator of structural complexity, basal area, which is related to the total woody biomass (and consequently, to productivity), and stem density, related to the successional stage and competition within forest stands. Furthermore, four additional structural variables were visually assessed: total vegetation cover (including overstorey), litter cover, moss cover and bare soil cover, representing the general condition of forest ground. They are recognized as biotic drivers and suitable/unsuitable microhabitats especially for the understorey (e.g., germination, seedling establishment; Kovács, Tinya, \& Ódor, 2017).

Each plot was assigned to different classes describing previous land use (in terms of years since a plot has been forested, i.e., $<25$, 25-100 years, etc.), current land use (if logged, distinguishing recent from dated treatments), and the current type of management (i.e., high forest, under development to high forest, coppice; see Nieuwenhuis, 2000). For instance, in a plot managed as coppice since 
350 years, under current treatments (i.e., within 10 years), the variable previous land use assumes value 1 (i.e., forested $>300$ years), the current land use value 3 (i.e., logged within 10 years), and the type of management value 3 (i.e., coppice; see Table 1). The stand age was defined as the mean age of the dominant storey (expressed in classes, Table 1). Furthermore, two variables related to deadwood were considered. Deadwood removal (binary, Table 1) is linked to management practices undertaken in fear of the spread of diseases, pests, or fires (Travaglini et al., 2007). Total deadwood is the total volume of deadwood (standing and fallen dead trees, coarse woody debris, stumps and snags, expressed in $\mathrm{m}^{3}$; Puletti, Giannetti, Chirici, $\&$ Canullo, 2017) and is often used as a proxy of disturbance intensity (Duncker et al., 2012; Green \& Peterken, 1997; Lombardi, Lasserre, Tognetti, \& Marchetti, 2008). Structural and land-use variables were defined according to the reference manual of the ICP Forests, and collected by coordinated crews of professionals and staff of the National Forest Service (WGFB 2011).

\section{3 | Plant functional traits}

We selected the three key functional traits of the LHS scheme (Westoby, 1998) that are independent of each other and represent the major axes of plant strategies. They are associated with the response of plants to environmental factors (response traits, sensu Lavorel \& Garnier, 2002). These traits are specific leaf area (SLA), a proxy of plant growth and a good surrogate for ability to use light efficiently; plant height $(H)$, related to competitive ability and access to the vertical light gradient; and seed mass (SM), having implications for the space/time dispersal ability and indicative of seedling establishment (Westoby, 1998). They have been found to be responsive to the above-mentioned climatic, soil, vegetation structure and land-use factors (Campetella et al., 2011; Le Bagousse-Pinguet et al., 2017; Moles et al., 2009, 2014; Pakeman et al., 2009).

The effect of individual species on ecosystem properties is related to their relative abundance in the community, and trait values of the dominant species have a proportionally greater effect than those of less abundant ones (Grime, 1998; Wasof et al., 2018). Therefore, we (a) selected from each plot all the species contributing to reach a relative cumulative coverage of $80 \%$ at the plot level; (b) attributed trait values to these species;, and (c) weighted trait values according to species coverage at plot level, in order to obtain community-weighted mean (CWM) values for each trait (Garnier et al., 2004; Lavorel \& Garnier, 2002). Seedlings of tree species were excluded. Trait values were obtained from the literature and databases (Campetella et al., 2011; Kleyer et al., 2008; Royal Botanical Gardens Kew, 2008).

\section{4 | Data analysis}

\subsection{1 | Data preparation}

The matrix of plot $x$ species data was combined with the matrix of species $\times$ trait data to provide a matrix of trait $\times$ plot data, which formed the basis for all the analyses. Weighted mean traits were log-transformed (Dainese, Scotton, Clementel, Pecile, \& Lepš, 2012; Pakeman et al., 2009; Westoby, 1998), since the original values were not normally distributed, and the transformation significantly increased the level of variation explained for all the selected traits.

\subsection{2 | Variance partitioning}

Variance partitioning (Borcard, Legendre, \& Drapeau, 1992) was used to identify the contributions of climate, soil, vegetation structure and land use, alone and in combination, to explaining the variation in community-weighted mean trait values. Variance partitioning has frequently been used to look at how different groups of environmental factors control species and trait distributions (Pakeman et al., 2009). In effect, it is redundancy analysis, linearly relating CWM values to groups of variables.

\subsection{3 | Generalized additive models}

In order to explore the single trait-environment relationships, we used generalized additive models (GAMs), which are nonparametric extensions of generalized linear models (GLMs), in which the linear predictor is substituted with an additive predictor (Hastie \& Tibshirani, 1990). Due to their nonparametric nature, GAMs are more data-driven than their parametric counterpart GLMs, and permit both linear and complex additive response shapes within the same models (Venables \& Ripley, 2002, pp. 271-300). For these specific models, the response variables $(y)$ were defined as the community-weighted mean for each of the three selected plant functional traits, while climatic, soil, structural and land-use covariates were used as predictor variables. To avoid multicollinearity, GAM model selection was done by Restricted Maximum Likelihood (REML) with automatic variable selection based on adding penalties to successive variables (Bradbury et al., 2014; Marra \& Wood, 2011). In order to reduce overfitting of the regression models, we reduced the number of nods in the smoothed functions and used a restricted maximum likelihood estimator (Madani et al., 2018).

All statistical analyses were performed in $R$, version 3.4.4 ( $R$ Foundation for Statistical Computing, Vienna, Austria). In particular, the mgcv R package (function gam) was used for the generalized additive models and the vegan $\mathrm{R}$ package (function varpart) served for variance partitioning (Borcard et al., 1992; Legendre \& Legendre, 2012; Wood, 2006). The chosen methods treat both numerical and categorical predictors (see Pakeman et al., 2009 for variance partitioning, and Pöyry, Luoto, Heikkinen, \& Saarinen, 2008 for GAMs).

\section{3 | RESULTS}

\section{1 | Partitioned trait-environment relationships}

Climate alone explained the largest proportion of the variation of $\mathrm{H}$ (12.6\%), SLA (7.7\%) and SM (8.6\%). Soil properties alone explained a small fraction of the $H(1.0 \%)$ and SLA (2.1\%) variation, while 
FIGURE 2 Results of partitioning variance (adjusted $R^{2}$ in \%) from climate, soil, forest structure and land-use variables for understorey CWM values of plant height $(H)$, specific leaf area (SLA) and seed mass (SM). Negative effects of groups of variables are not shown (see Appendix S1 for detailed results) [Colour figure can be viewed at wileyonlinelibrary. com]

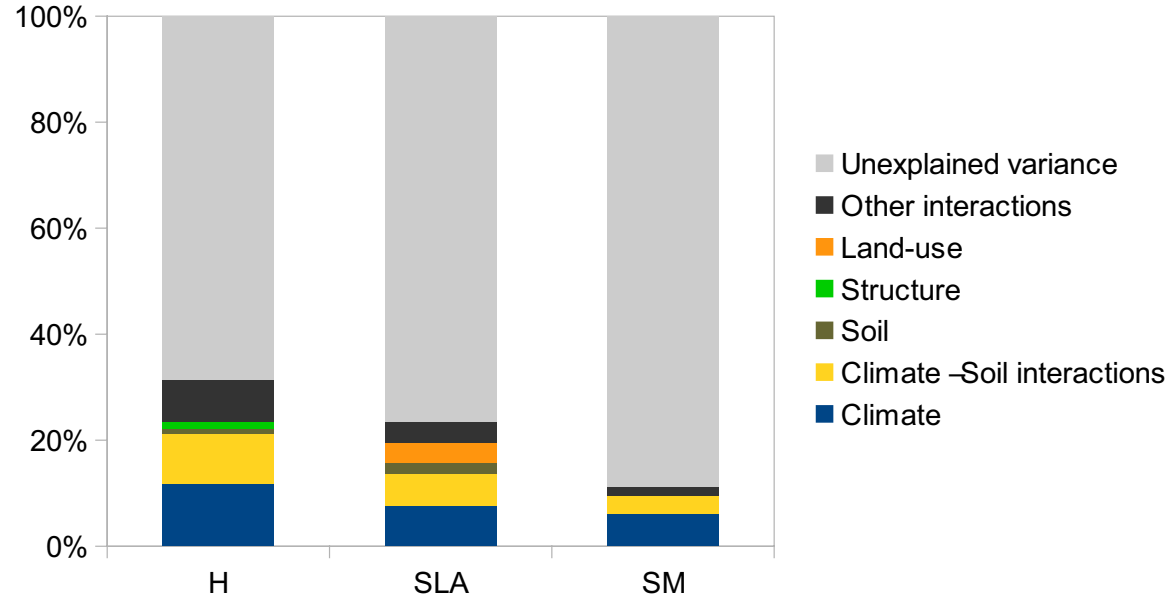

climate-soil interactions explained a higher amount of trait variation ( $H, 9.8 \%$; SLA, 6.1\% and SM, 5.1\%). Forest structure and land use controlled a small amount of trait variation, mainly in combination with other groups of variables. Land-use factors alone were important in explaining only SLA variation (3.6\%), while interactions among different variables have some influence on trait variation, mainly for $\mathrm{H}$ (8.2\%) and SLA (4.1\%), followed by SM (2.2\%; Figure 2; Appendix S1).

\section{2 | Trait patterns along the gradients}

For $\mathrm{H}$, the final GAM explained $36.0 \%$ (adjusted $R^{2}$ ) of the trait variation. Four significant variables related to climate and soil were selected (temperature seasonality, precipitation seasonality, maximum temperature of the warmest month, subsoil P; Figure 3; Appendix S2). Understorey $H$ decreased along the temperature seasonality gradient $(p<0.001)$ and increased along the gradient of maximum temperature of the warmest month $(p<0.001)$, especially for stands with maximum temperature $>15^{\circ} \mathrm{C}$. Community understorey $\mathrm{H}$ decreased with increasing precipitation seasonality $(p=0.018)$ and increased with increasing subsoil P $(p=0.005)$.

For SLA, the final GAM explained $26.0 \%\left(\operatorname{Adj} . R^{2}\right.$ ) of the trait variation. Five significant variables related to climate, soil and forest structure were selected (Figure 3; Appendix S2): temperature seasonality $(p=0.014)$, PET $(p<0.001)$, total $N(p=0.006)$, litter cover $(p=0.004)$, and basal area $(p=0.025)$. Understorey SLA increased along temperature seasonality, total $\mathrm{N}$ and basal area gradients, whereas it decreased along the PET gradient from approximately $600 \mathrm{~mm}$. Finally, SLA and litter cover showed a quadratic relationship.

For SM, the final GAM explained $15.7 \%\left(\operatorname{Adj} . R^{2}\right.$ ) of the trait variation. The four significant predictor variables selected refer to climate and vegetation structure (PET, isothermality, $\mathrm{P}$ of the wettest month, moss cover; Figure 3; Appendix S2). Understorey SM increased along the PET gradient $(p=0.012)$ in stands with values $>600 \mathrm{~mm}$, and decreased in wetter stands characterized by precipitation of the wettest month approximately $>100 \mathrm{~mm}(p=0.003)$. Additionally, SM increased along the isothermality gradient ( $p=$ 0.050 ), and decreased along the moss cover gradient ( $p=0.033$ ) but only for cover values $<40 \%$.

\section{4 | DISCUSSION}

\subsection{Climate and climate-soil interactions as the main drivers of LHS traits}

Our approach quantified the role of climate and local environmental factors in shaping abundance-weighted trait patterns of forest understorey at the biogeographic scale. Climate was shown to exert the greatest independent effect on SLA, $H$ and SM. This result is in line with several studies conducted in forest ecosystems (Shiono et al., 2015; Swenson \& Weiser, 2010; Vanneste et al., 2019) and confirms the role of climate as a primary macro filter shaping the community mean plant traits. Local environmental factors alone (namely, soil, land use and forest structure) showed a minor role in influencing understorey traits. Our study area spans three biogeographic regions and probably the large variability of climatic conditions may have contributed to climate being the key driver of trait patterns, overruling the effects of local environmental factors. However, local soil conditions in interaction with climate play a significant role in explaining the variation of the three traits. Simpson et al. (2016) suggested the significance of climate-soil interactions in influencing plant traits of tree communities. We provide evidence that climate-soil interactions are important drivers of community-weighted mean traits also in forest understorey.

FIG URE 3 The estimated smoothers for plant height (H), specific leaf area (SLA) and seed mass (SM) obtained by generalized additive models (GAMs) that include the selected explanatory variables (significant values: ${ }^{* * *} p<0.001,{ }^{* *} p<0.01$, and ${ }^{*} p<0.05$ ). Confidence intervals (95\%) are indicated with the grey areas. The $x$-axis represents the independent variable; the $y$-axis represents the smooth effect of the independent variable on the dependent variable. For units of measurement and categories, see Table 1. Vertical tick marks on the $x$-axis represent the values of covariates 

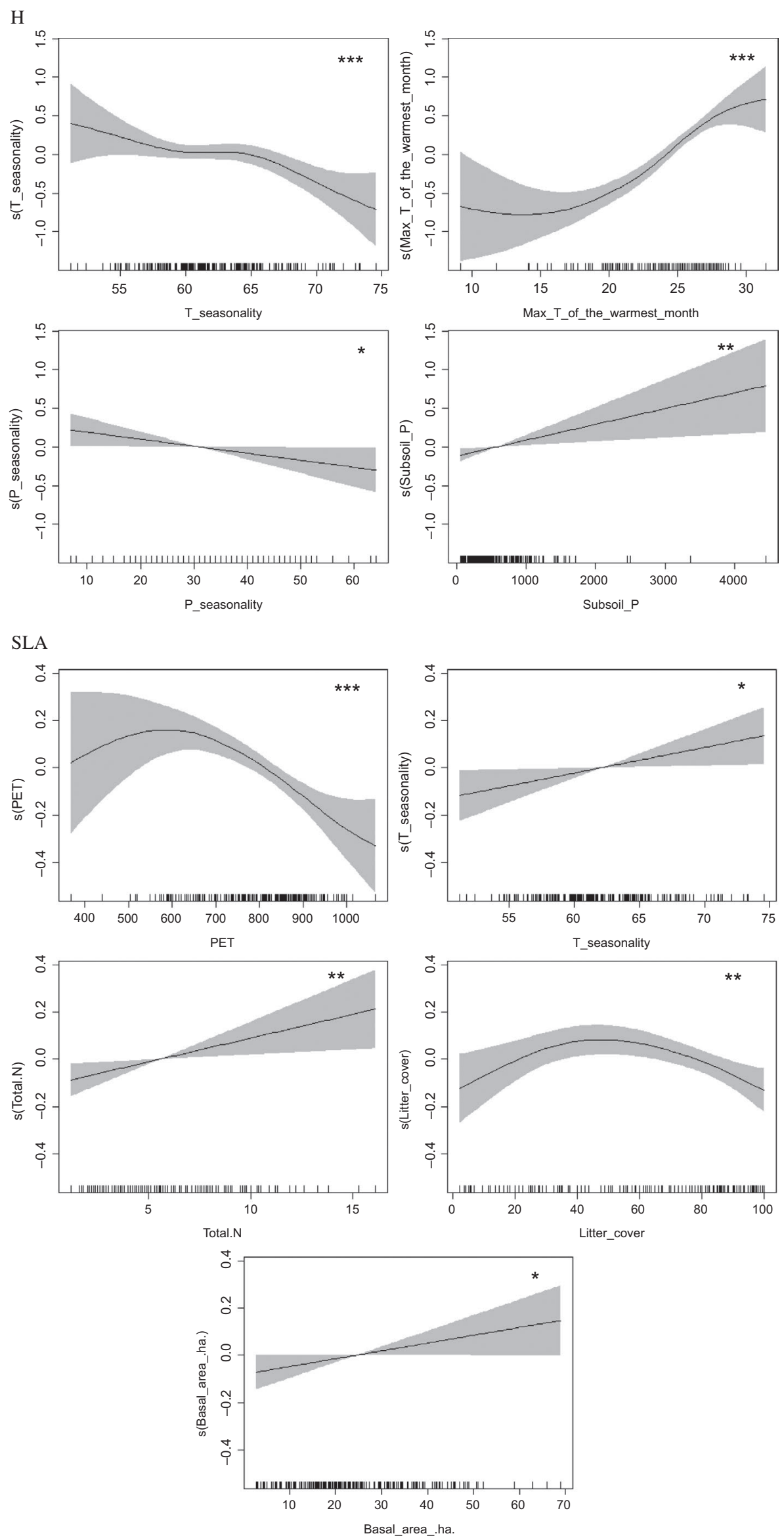
SM
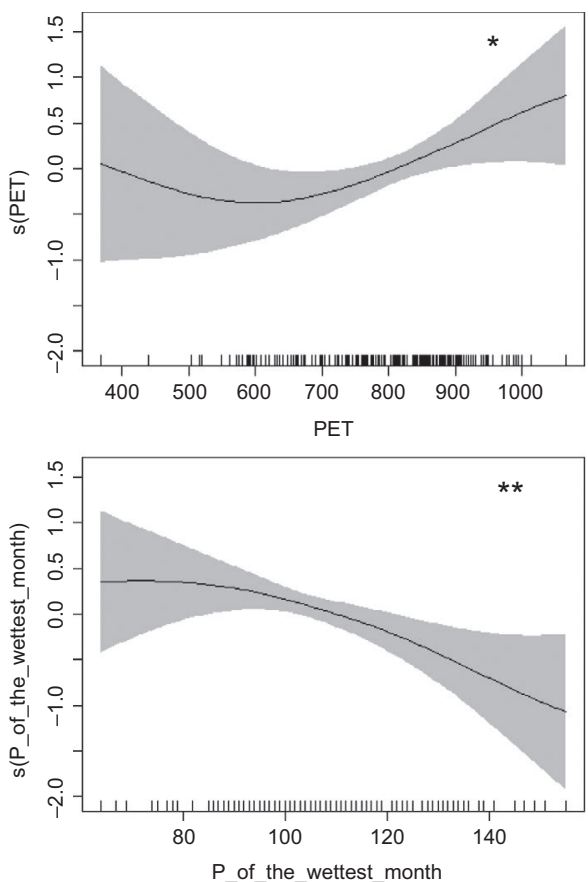

FIGURE 3 (Continued)

The limited effect of land use and forest structure on community mean plant traits of the understorey at the biogeographic scale is in line with the findings of Vanneste et al. (2019). Indeed, structure and land use were shown to significantly affect plant traits in local studies where climate and soil parameters were relatively homogeneous (Aubin et al., 2007; Campetella et al., 2011). However, land-use parameters alone appeared to markedly influence only SLA, probably because they determine the light conditions of the ground layer. Indeed, light availability and patchiness are important drivers of understorey SLA in managed forests (Campetella et al., 2011; Dahlgren et al., 2006; Vanneste et al., 2019).

These findings imply that (a) broad scale trait-environment relationship in forests can be captured by the interaction of macroclimate and local soil conditions, and (b) climate change as well as soil nutrient variation, and to a less extent land-use change, can potentially affect the future functioning of forest understories. However, further studies including traits related to other functions (i.e., space occupancy and recovery after damage) and based on direct measures of land-use type and intensity are needed to confirm our results.

\subsection{Direction of trait-environment relationships}

Temperature-related variables were correlated with all three plant traits, which is in line with recent findings (Moles et al., 2014; Reich \& Oleksyn, 2004; Šímová et al., 2018). In particular, temperature seasonality was an important driver of changes in understorey mean values of $H$ and SLA: forest stands characterized by high temperature variation across seasons (thermophilous deciduous and broadleaved evergreen forests located in the Mediterranean Region of Italy) were characterized by shorter understorey communities with high-SLA values, while
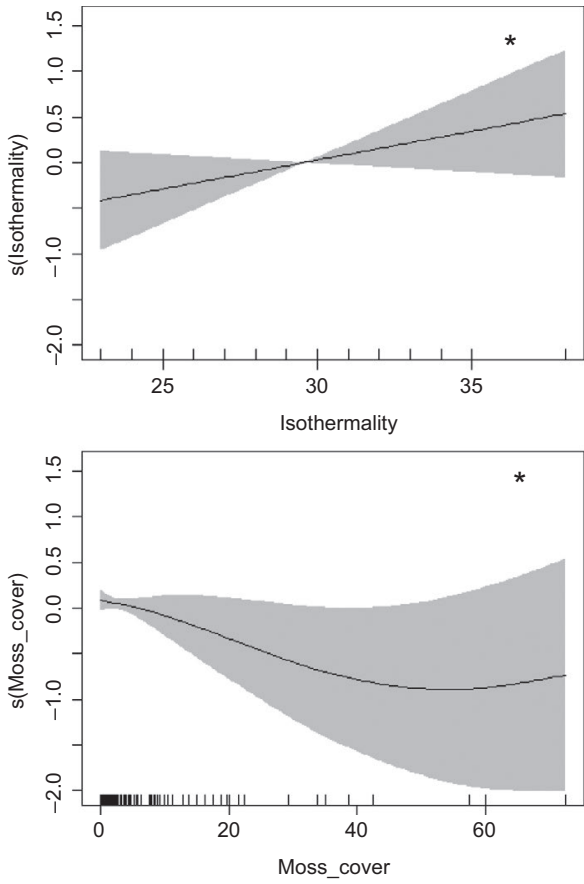

forest stands with low temperature variation across seasons (forests of the hilly and mountainous belt of northern and central Italy) were characterized by taller understorey communities with low SLA values.

PET was shown to control both SLA and SM variation. Understorey communities with lower SLA and higher SM occurred in drier forest stands. SLA is related to the water use strategy of species: a lower SLA is associated with a slower plant growth rate, which usually occurs under water stress in order to improve the efficiency of water use (Wellstein et al., 2017). In parallel, larger seeds may act as a buffer against low water availability (Dainese et al., 2012; Tautenhahn et al., 2008), favoring establishment success and seedling performance (Leishman \& Westoby, 1994).

Furthermore, understorey plants are taller on soils with higher productivity (higher subsoil P), confirming previous findings (Davis, Thompson, \& Grime, 2005; Diaz et al., 2004; Tautenhahn et al., 2008). Indeed, phosphorus is an essential soil element related to plant growth in many ecosystems (Lambert, Raven, Shaver, \& Smith, 2008; Quesada et al., 2012). In addition, high SLA values are associated with soils containing high total N. As a leaf economic trait, SLA has been found to be controlled by soil fertility, since nutrient supply has an important role as modulator of leaf level photosynthetic properties (Lloyd et al., 2015; Ordonez et al., 2009). Also, high-SLA understorey communities occur in mature forest stands with a greater amount of woody biomass (i.e., higher values of basal area). Mature forests are usually characterized by a shady understorey environment which in turn can favor species with large SLA (Dahlgren et al., 2006). Indeed, large SLA is associated with high photosynthetic capacity and short leaf turnover time, characteristics that may enable flexible responses to light patchiness and appear to be particularly advantageous in late-succession forest stands (Campetella et al., 2011). 


\section{3 | Data limitation and future perspectives}

The total variation of CWM trait values explained by the selected environmental variables ( $H, 29.6 \%$; SLA, 23.2\%; SM, 8.2\%) was similar to that found in studies performed in forests (e.g., 9\%-31\%; Vanneste et al., 2019) and lower than that found in studies performed in grasslands (e.g., 45-50\%; Pakeman et al., 2009). Probably the complexity of forest ecosystems calls for the inclusion of more biotic and abiotic variables. For instance, several approaches demonstrated how the light reaching the ground layer conditioned plant functional traits of the understorey (see Campetella et al., 2011; Dahlgren et al., 2006; Hedwall \& Brunet, 2016). Direct measurements of parameters that better describe the understorey environment (i.e., Photosynthetic Active Radiation) instead of the use of proxy variables, could be fundamental for increasing the explained variance in such forest contexts.

The trait-environment patterns reported in the present study depend on species turnover or changes in species cover values, and not on intraspecific variation. Thus, future studies that account for intraspecific trait variability could be useful, since it can play a fundamental role in plant community responses to environmental gradients (Kichenin, Wardle, Peltzer, Morse, \& Freschet, 2013).

\section{5 | CONCLUSIONS}

This study spanned a large biogeographical gradient using a dataset representative of the Italian forests, and demonstrated how the variation in abundance-weighted mean trait values of the understorey is mainly influenced by macroclimate alone and in interaction with local soil conditions. Land use and forest structure had a smaller influence on trait patterns. However, the land-use variables alone showed a significant effect on SLA. These results highlighted the need to integrate at least soil features as local drivers of trait variation in functional biogeography studies aimed at exploring broad-scale trait-environment relationships (Bruelheide et al., 2018). Moreover, our findings could be significant in the light of global changes: incorporating local-scale soil parameters in modeling frameworks can significantly improve our ability to predict the functional responses of forest understorey (Simpson et al., 2016, for trees).

\section{ACKNOWLEDGEMENTS}

This work was partially supported by the Thünen Institute (Hamburg) and the ICP Forests' Italian Focal Centre (CUFA, Comando per la Tutela della Biodiversità e dei Parchi - Ufficio Studi e Progetti, Roma). Sheila Beatty kindly corrected the English usage of the manuscript. SB was supported by the GINOP-2.3.2-15-2016-00019 project.

\section{AUTHORS CONTRIBUTIONS}

SCh, CW and RC conceived the ideas; SCa, AA, NP, DG collected data on explanatory variables; ES analysed the data; SCh, ES, CW, SCa, AA, NP, DG, GC, SB, RC led the writing of the manuscript.

\section{DATA AVAILABILITY STATEMENT}

Species presence/absence and coverage, as well as explanatory variable were obtained from the transnational Level I network for monitoring the forest health status in Europe (ICP Forests, http:// icp-forests.net/). Traits data were collected from existing databases (Campetella et al., 2011; Kleyer et al., 2008; Royal Botanical Gardens Kew, 2008).

\section{ORCID}

Stefano Chelli iD https://orcid.org/0000-0001-7184-8242

\section{REFERENCES}

Allegrini, M.-C., Canullo, R., \& Campetella, G. (2009). ICP-Forests (International Co-operative Programme on Assessment and Monitoring of Air Pollution Effects on Forests): Quality Assurance procedure in plant diversity monitoring. Journal of Environmental Monitoring, 11(2), 782-787.

Andreetta, A., Cecchini, G., Bonifacio, E., Comolli, R., Vingiani, S., \& Carnicelli, S. (2016). Tree or soil? Factors influencing humus form differentiation in Italian forests. Geoderma, 264(A), 195-204.

Andreetta, A., Ciampalini, R., Moretti, P., Vingiani, S., Poggio, G., Matteucci, G., ... Carnicelli, S. (2011). Forest humus forms as potential indicators of soil carbon storage in Mediterranean environments. Biology and Fertility of Soils, 47(1), 31-40. https://doi.org/10.1007/ s00374-010-0499-z

Andreetta, A., Macci, C., Giansoldati, V., Masciandaro, G., \& Carnicelli, S. (2013). Microbial activity and organic matter composition in Mediterranean humus forms. Geoderma, 209-210, 198-208. https:// doi.org/10.1016/j.geoderma.2013.06.010

Aubin, I., Gachet, S., Messier, C., \& Bouchard, A. (2007). How resilient are northern hardwood forests to human disturbance? An evaluation using a plant functional group approach. Ecoscience, 14(2), 259-271. https://doi.org/10.2980/1195-6860(2007)14[259:hranh f]2.0.co;2

Aubin, I., Messier, C., \& Bouchard, A. (2008). Can plantations develop understory biological and physical attributes of naturally regenerated forests? Biological Conservation, 141(10), 2461-2476. https://doi. org/10.1016/j.biocon.2008.07.007

Bartels, S. F., \& Chen, H. Y. H. (2013). Interactions between overstorey and understorey vegetation along an overstorey compositional gradient. Journal of Vegetation Science, 24(3), 543-552. https://doi. org/10.1111/j.1654-1103.2012.01479.x

Borcard, D., Legendre, P., \& Drapeau, P. (1992). Partialling out the spatial component of ecological variation. Ecology, 73(3), 1045-1055. https ://doi.org/10.2307/1940179

Borgy, B., Violle, C., Choler, P., Denelle, P., Munoz, F., Kattge, J., ... Garnier, E. (2017a). Plant community structure and nitrogen inputs modulate the climate signal on leaf traits. Global Ecology and Biogeography, 26(10), 1138-1152. https://doi.org/10.1111/ geb.12623

Borgy, B., Violle, C., Choler, P., Garnier, E., Kattge, J., Loranger, J., ... Viovy, N. (2017b). Sensitivity of community-level trait-environment relationships to data representativeness: A test for functional biogeography. Global Ecology and Biogeography, 26(6), 729-739. https://doi. org/10.1111/geb.12573

Bradbury, G., Trinder, M., Furness, B., Banks, A. N., Caldow, R. W. G., \& Hume, D. (2014). Mapping seabird sensitivity to offshore wind farms. PLoS ONE, 9(9), e106366. https://doi.org/10.1371/journ al.pone.0106366 
Bruelheide, H., Dengler, J., Purschke, O., Lenoir, J., Jiménez-Alfaro, B., Hennekens, S. M., ... Jandt, U. (2018). Global trait-environment relationships of plant communities. Nature Ecology \& Evolution, 2(12), 1906-1917. https://doi.org/10.1038/s41559-018-0699-8

Campetella, G., Botta-Dukát, Z., Wellstein, C., Canullo, R., Gatto, S., Chelli, S., ... Bartha, S. (2011). Patterns of plant trait-environment relationships along a forest succession chronosequence. Agriculture Ecosystems and Environment, 145(1), 38-48. https://doi. org/10.1016/j.agee.2011.06.025

Canullo, R., Campetella, G., Mucina, L., Chelli, S., Wellstein, C., \& Bartha, S. (2011a). Patterns of clonal growth modes along a chronosequence of post-coppice forest regeneration in beech forests of Central Italy. Folia Geobotanica, 46(2-3), 271-288. https://doi.org/10.1007/ s12224-010-9087-0

Canullo, R., Starlinger, F., Granke, O., Fischer, R., Aamlid, D., \& Neville, P. (2011b). Assessment of ground vegetation. Manual Part VII, p. 18. Hamburg, Germany: UNECE ICP Forests Programme Coordinating Centre.

Cervellini, M., Fiorini, S., Cavicchi, A., Campetella, G., Simonetti, E., Chelli, S., ... Gimona, A. (2017). Relationships between understory specialist species and local management practices in coppiced forests Evidence from the Italian Apennines. Forest Ecology and Management, 385, 35-45. https://doi.org/10.1016/j.foreco.2016.11.027

Chiarucci, A. (2007). To sample or not to sample? That is the question..., for the vegetation scientist. Folia Geobotanica, 42, 209-216. https:// doi.org/10.1007/bf02893887

Colombaroli, D., \& Tinner, W. (2013). Determining the long-term changes in biodiversity and provisioning services along a transect from Central Europe to the Mediterranean. The Holocene, 23(11), 16251634. https://doi.org/10.1177/0959683613496290

Costantini, E. A. C., Barbetti, R., Fantappiè, M., L'Abate, G., Lorenzetti, R., \& Magini, S. (2013). Pedodiversity. In E. Costantini, \& C. Dazzi (Eds), The Soils of Italy (pp. 105-178). Dordrecht, Netherlands: Springer.

Dahlgren, J. P., Eriksson, O., Bolmgren, K., Strindell, M., \& Ehrlén, J. (2006). Specific leaf area as a superior predictor of changes in field layer abundance during forest succession. Journal of Vegetation Science, 17(5), 577-582. https://doi.org/10.1111/j.1654-1103.2006. tb02481.x

Dainese, M., Scotton, M., Clementel, F., Pecile, A., \& Lepš, J. (2012). Do climate, resource availability, and grazing pressure filter floristic composition and functioning in Alpine pastures? Community Ecology, 13(1), 45-54. https://doi.org/10.1556/comec.13.2012.1.6

Davis, M. A., Thompson, K., \& Grime, J. P. (2005). Invasibility: the local mechanism driving community assembly and species diversity. Ecography, 28(5), 696-704. https://doi.org/10.1111/j.2005.0906-7590.04205.x

Diaz, S., Hodgson, J. G., Thompson, K., Cabido, M., Cornelissen, J. H. C., Jalili, A., ... Zak, M. R. (2004). The plant traits that drive ecosystems: Evidence from three continents. Journal of Vegetation Science, 15(3), 295-304. https://doi.org/10.1111/j.1654-1103.2004.tb02266.x

Duncker, P. S., Raulund-Rasmussen, K., Gundersen, P., Katzensteiner, K., De Jong, J., Ravn, H. P., ... Spiecker, H. (2012). How forest management affects ecosystem services, including timber production and economic return: synergies and trade-offs. Ecology and Society, 17(4), 50. https:// doi.org/10.5751/ES-05066-170450

Evans, J. D. (1996). Straightforward statistics for the behavioral sciences. Belmont, CA: Thomson Brooks/Cole Publishing.

Garnier, E., Cortez, J., Billès, G., Navas, M.-L., Roumet, C., Debussche, M., ... Toussaint, J.-P. (2004). Plant functional markers capture ecosystem properties during secondary succession. Ecology, 85(9), 2630-2637. https://doi.org/10.1890/03-0799

Gilliam, F. S. (2006). Response of the herbaceous layer of forest ecosystems to excess nitrogen deposition. Journal of Ecology, 94(6), 11761191. https://doi.org/10.1111/j.1365-2745.2006.01155.x

Gilliam, F. S. (2014). The herbaceous layer in forests of eastern North America. New York, NY: Oxford University Press.
Green, P., \& Peterken, G. F. (1997). Variation in the amount of dead wood in the woodlands of the Lower Wye Valley, UK in relation to the intensity of management. Forest Ecology and Management, 98(3), 229238. https://doi.org/10.1016/s0378-1127(97)00106-0

Grime, J. P. (1998). Benefits of plant diversity to ecosystems: Immediate, filter and founder effects. Journal of Ecology, 86(6), 902-910. https:// doi.org/10.1046/j.1365-2745.1998.00306.x

Hastie, T., \& Tibshirani, R. (1990). Generalized additive models. London, UK: Chapman and Hall.

Hättenschwiler, S., \& Körner, C. (1996). Effects of elevated $\mathrm{CO}_{2}$ and increased nitrogen deposition on photosynthesis and growth of understory plants in spruce model ecosystems. Oecologia, 106(2), 172-180. https://doi.org/10.1007/bf00328596

Hedwall, P.-O., \& Brunet, J. (2016). Trait variations of ground flora species disentangle the effects of global change and altered land-use in Swedish forests during 20 years. Global Change Biology, 22(12), 4038-4047. https://doi.org/10.1111/gcb.13329

Hijmans, R. J., Cameron, S. E., Parra, J. L., Jones, P. G., \& Jarvis, A. (2005). Very high resolution interpolated climate surfaces for global land areas. International Journal of Climatology, 25(15), 1965-1978. https ://doi.org/10.1002/joc.1276

Kichenin, E., Wardle, D. A., Peltzer, D. A., Morse, C. W., \& Freschet, G. T. (2013). Contrasting effects of plant inter-and intraspecific variation on community-level trait measures along an environmental gradient. Functional Ecology, 27(5), 1254-1261. https://doi. org/10.1111/1365-2435.12116

Kleyer, M., Bekker, R. M., Knevel, I. C., Bakker, J. P., Thompson, K., Sonnenschein, M., ... Peco, B. (2008). The LEDA Traitbase: a database of life-history traits of the Northwest European Flora. Journal of Ecology, 96(6), 1266-1274. https://doi.org/10.1111/j.1365-2745.2008.01430.x

Kovács, B., Tinya, F., \& Ódor, P. (2017). Stand structural drivers of microclimate in mature temperate mixed forests. Agricultural and Forest Meteorology, 234-235, 11-21. https://doi.org/10.1016/j.agrfo rmet.2016.11.268

Lambert, H., Raven, J. A., Shaver, G. R., \& Smith, S. E. (2008). Plant nutrient-acquisition strategies change with soil age. Trends in Ecology \& Evolution, 23(2), 95-103. https://doi.org/10.1016/j.tree.2007.10.008

Lavorel, S., \& Garnier, E. (2002). Predicting changes in community composition and ecosystem functioning from plant traits: revisiting the Holy Grail. Functional Ecology, 16(5), 545-556. https://doi. org/10.1046/j.1365-2435.2002.00664.x

Le Bagousse-Pinguet, Y., Gross, N., Maestre, F. T., Maire, V., de Bello, F., Fonseca, C. R., ... Liancourt, P. (2017). Testing the environmental filtering concept in global drylands. Journal of Ecology, 105(4), 10581069. https://doi.org/10.1111/1365-2745.12735

Legendre, P., \& Legendre, L. (2012). Numerical ecology, 3rd English ed. Amsterdam, tThe Netherlands: Elsevier Science BV.

Leishman, M. R., \& Westoby, M. (1994). The role of seed size in seedling establishment in dry soil conditions - experimental evidence from semi arid species. Journal of Ecology, 82(2), 249-258. https://doi. org/10.2307/2261293

Lloyd, J., Domingues, T. F., Schrodt, F., Ishida, F. Y., Feldpausch, T. R., Saiz, G., ... Phillips, O. L. (2015). Edaphic, structural and physiological contrasts across Amazon Basin forest-savanna ecotones suggest a role for potassium as a key modulator of tropical woody vegetation structure and function. Biogeosciences, 12(22), 6529-6571. https:// doi.org/10.5194/bg-12-6529-2015

Lombardi, F., Lasserre, B., Tognetti, R., \& Marchetti, M. (2008). Deadwood in relation to stand management and forest type in Central Apennines (Molise, Italy). Ecosystems, 11, 882-894. https:// doi.org/10.1007/s10021-008-9167-7

Madani, N., Kimball, J. S., Ballantyne, A. P., Affleck, D. L. R., van Bodegom, P. M., Reich, P. B., ... Running, S. W. (2018). Future global productivity will be affected by plant trait response to climate. Scientific Reports, 8, 2870. https://doi.org/10.1038/s41598-018-21172-9 
Marra, G., \& Wood, S. (2011). Practical variable selection for generalized additive models. Computational Statistics and Data Analysis, 55(7), 2372-2387. https://doi.org/10.1016/j.csda.2011.02.004

Moles, A. T., Perkins, S. E., Laffan, S. W., Flores-Moreno, H., Awasthy, M., Tindall, M. L., ... Bonser, S. P. (2014). Which is a better predictor of plant traits: Temperature or precipitation? Journal of Vegetation Science, 25(5), 1167-1180. https://doi.org/10.1111/jvs.12190

Moles, A. T., Warton, D. I., Warman, L., Swenson, N. G., Laffan, S. W., Zanne, A. E., ... Leishman, M. R. (2009). Global patterns in plant height. Journal of Ecology, 97, 923-932. https://doi. org/10.1111/j.1365-2745.2009.01526.x

Nieuwenhuis, M. (2000). Terminology of forest management planning. Terms and definitions in English - equivalent terms in German, French, Spanish, Italian, Portuguese and Japanese. IUFRO 4.04.07 SilvaPlan und SilvaVoc, IUFRO World Series, Vol. 9-en. Vienna, Austria: IUFRO.

Ordonez, J. C., van Bodegom, P. M., Witte, J.-P. M., Wright, I. J., Reich, P. B., \& Aerts, R. (2009). A global study of relationships between leaf traits, climate and soil measures of nutrient fertility. Global Ecology and Biogeography, 18, 137-149. https://doi. org/10.1111/j.1466-8238.2008.00441.x

Pakeman, R. J., Lepš, J., Kleyer, M., Lavorel, S., Garnier, E., \& the VISTA consortium (2009). Relative climatic, edaphic and management controls of plant functional trait signatures. Journal of Vegetation Science, 20(1), 148-159. https://doi. org/10.1111/j.1654-1103.2009.05548.x

Pöyry, J., Luoto, M., Heikkinen, R. K., \& Saarinen, K. (2008). Species traits are associated with the quality of bioclimatic models. Global Ecology and Biogeography, 17(3), 403-414. https://doi. org/10.1111/j.1466-8238.2007.00373.x

Puletti, N., Giannetti, F., Chirici, G., \& Canullo, R. (2017). Deadwood distribution in European forests. Journal of Maps, 13(2), 733-736. https ://doi.org/10.1080/17445647.2017.1369184

Quesada, C. A., Phillips, O. L., Schwarz, M., Czimczik, C. I., Baker, T. R., Patiño, S., ... Alvarez, D. A. (2012). Basin-wide variations in Amazon forest structure and function are mediated by both soils and climate. Biogeosciences, 9(6), 2203-2246. https://doi.org/10.5194/ bg-9-2203-2012

Reich, P. B., \& Oleksyn, J. (2004). Global patterns of plant leaf N and P in relation to temperature and latitude. Proceedings of the National Academy of Sciences of the United States of America, 101(30), 1100111006. https://doi.org/10.1073/pnas.0403588101

Rowe, E. C., Emmett, B. A., Smart, S. M., \& Frogbrook, Z. L. (2011). A new net mineralizable nitrogen assay improves predictions of floristic composition. Journal of Vegetation Science, 22(2), 251-261. https:// doi.org/10.1111/j.1654-1103.2010.01241.x

Royal Botanical Gardens Kew. 2008. Seed Information Database (SID), Version 7.1. Retrieved from http://data.kew.org/sid/ (May 2008).

Shiono, T., Kusumoto, B., Maeshiro, R., Fujii, S. J., Götzenberger, L., de Bello, F., \& Kubota, Y. (2015). Climatic drivers of trait assembly in woody plants in Japan. Journal of Biogeography, 42(6), 1176-1186. https://doi.org/10.1111/jbi.12503

Shipley, B., De Bello, F., Cornelissen, J. H. C., Laliberté, E., Laughlin, D. C., \& Reich, P. B. (2016). Reinforcing loose foundation stones in trait-based plant ecology. Oecologia, 180(4), 923-931. https://doi. org/10.1007/s00442-016-3549-x

Šímová, I., Violle, C., Svenning, J.-C., Kattge, J., Engemann, K., Sandel, B., ... Enquist, B. J. (2018). Spatial patterns and climate relationships of major plant traits in the New World differ between woody and herbaceous species. Journal of Biogeography, 45(4), 895-916. https:// doi.org/10.1111/jbi.13171

Simpson, A. H., Richardson, S. J., \& Laughlin, D. C. (2016). Soil-climate interactions explain variation in foliar, stem, root and reproductive traits across temperate forests. Global Ecology and Biogeography, 25(8), 964-978. https://doi.org/10.1111/geb.12457
Swenson, N. G., \& Weiser, M. D. (2010). Plant geography upon the basis of functional traits: aAn example from eastern North American trees. Ecology, 91(8), 2234-2241. https://doi.org/10.1890/09-1743.1

Tautenhahn, S., Heilmeier, H., Gotzenberger, L., Klotz, S., Wirth, C., \& Kühn, I. (2008). On the biogeography of seed mass in Germany distribution patterns and environmental correlates. Ecography, 31(4), 457-468. https://doi.org/10.1111/j.0906-7590.2008.05439.x

Tonteri, T., Salemaa, M., Rautio, P., Hallikainen, V., Korpela, L., \& Merilä, P. (2016). Forest management regulates temporal change in the cover of boreal plant species. Forest Ecology and Management, 381, 115124. https://doi.org/10.1016/j.foreco.2016.09.015

Trabucco, A., \& Zomer, R. J. (2009). Global Aridity Index (Global-Aridity) and Global Potential Evapo-Transpiration (Global-PET) Geospatial Database. CGIAR Consortium for Spatial Information, Published online. Retrieved from http://www.csi.cgiar.org

Travaglini, D., Barbati, A., Chirici, G., Lombardi, F., Marchetti, M., \& Corona, P. (2007). ForestBIOTA data on deadwood monitoring in Europe. Plant Biosystems, 141(2), 222-230. https://doi.org/10.1080/11263 500701401778

Vanneste, T., Valdés, A., Verheyen, K., Perring, M. P., BernhardtRömermann, M., Andrieu, E., ... De Frenne, P. (2019). Functional trait variation of forest understorey plant communities across Europe. Basic and Applied Ecology, 34, 1-14. https://doi.org/10.1016/j. baae.2018.09.004

Venables, W. N., \& Ripley, B. D. (2002). Random and mixed effects. In: Modern applied statistics with S. New York, NY: Springer.

Verheyen, K., Honnay, O., Motzkin, G., Hermy, M., \& Foster, D. R. (2003). Response of forest plant species to land-use change: A life-history trait-based approach. Journal of Ecology, 91(4), 563-577. https://doi. org/10.1046/j.1365-2745.2003.00789.x

Wasof, S., Lenoir, J., Tarek, H., Jamoneau, A., Gallet-Moron, E., Ampoorter, E., ... Decocq, G.. (2018). Dominance of individual plant species is more important than diversity in explaining plant biomass in the forest understorey. Journal of Vegetation Science, 29(3), 521-531. https ://doi.org/10.1111/jvs.12624

Wellstein, C., Poschlod, P., Gohlke, A., Chelli, S., Campetella, G., Rosbakh, S., ... Beierkuhnlein, C. (2017). Effects of extreme drought on specific leaf area of grassland species: A meta-analysis of experimental studies in temperate and sub-Mediterranean systems. Global Change Biology, 23(6), 2473-2481. https://doi.org/10.1111/ gcb.13662

Westoby, M. (1998). A Leaf-height-seed (LHS) plant ecology strategy scheme. Plant and Soil, 199(2), 213-227. https://doi. org/10.1023/a:1004327224729

Working Group on Forest Biodiversity (2011) Appendix 1: The BioSoil Forest Biodiversity Field Manual, version 1.0/1.1/1.1a for the field assessment 2006-07. In T. Durrant, J. San-Miguel-Ayanz, E. Schulte, \& A. S. Meyer (Eds.), Evaluation of BioSoil Demonstration Project: Forest Biodiversity (pp. 81-102). Luxembourg: Publications Office of the European Union. https://doi.org/10.2788/84823

Wood, S. (2006). Generalized additive models: An introduction with R. Boca Raton, FL: Chapman and Hall/CRC Press.

Wright, I. J., Reich, P. B., Cornelissen, J. H. C., Falster, D. S., Groom, P. K., Hikosaka, K., ... Westoby, M. (2005). Modulation of leaf economic traits and trait relationships by climate. Global Ecology and Biogeography, 14(5), 411-421. https://doi.org/10.1111/j.1466-822x. 2005.00172.x

Wright, I. J., Reich, P. B., Westoby, M., Ackerly, D. D., Baruch, Z., Bongers, F., ... Villar, R. (2004). The worldwide leaf economic spectrum. Nature, 428, 821-827. https://doi.org/10.1038/nature02403

Zemunik, G., Turner, B. L., Lambers, H., \& Laliberté, E. (2015). Diversity of plant nutrient-acquisition strategies increases during long-term ecosystem development. Nature Plants, 1, 15050. https://doi. org/10.1038/nplants.2015.50 


\section{SUPPORTING INFORMATION}

Additional supporting information may be found online in the Supporting Information section at the end of the article.

Appendix S1. Detailed results of variance partitioning

Appendix S2. Summary of the generalized additive models
How to cite this article: Chelli S, Simonetti E, Wellstein C, et al. Effects of climate, soil, forest structure and land use on the functional composition of the understorey in Italian forests. $J$ Veg Sci. 2019;30:1110-1121. https://doi.org/10.1111/ jvs.12792 